Discussion The available data suggest that IRA may have biological effects regardless of the potential temperature increase of tissues. Moreover, a synergistic action between IRA, visible radiation, UVB or UVA, may not be excluded, for instance regarding ROS production, modulation of cell signalling, induction of mutations and/or epigenetic changes, especially for prolonged and repeated exposures of skin and eye tissues. Waiting for new experimental and epidemiological data (including those obtained applying 'omics' technologies) protection of workers exposed to solar radiation should ideally include the shielding of IRA (although effective sunscreens are not yet available in this regard), while health surveillance should not ignore the possibility of synergistic effects. Finally, preventive pathways have to include, among others, education to healthy lifestyles.

\section{MAIN PRINCIPLES OF ELECTROMAGNETIC FIELD OCCUPATIONAL EXPOSURE RISKS MANAGEMENT IN RUSSIA}

N Rubtsova*, Yu Paltsev, L Pokhodzey, S Perov, A Tokarskiy. Federal State Budgetary Scientific Institution 'Izmerov Research Institute of Occupational Health'

\subsection{6/oemed-2018-ICOHabstracts. 1199}

Electromagnetic field (EMF) of power transmission, broadcasting systems, etc. are health risk factor. In case of occupational exposure EMF are purposeful risk factor; for other workers and general public EMF are enforces risk factor, and in case of different emitters (mobile phones, laptops, etc.) use EMF are voluntary risk factor.

The main principle of EMF occupational exposure risks management in Russia is based in concept of EMF 'cumulative' effects. Hygienic norms are time dependent, comprising a principle 'protection by time'. EMF hygienic standardisation in Russia is based on the results of hygienic, clinical-physiological, epidemiological and experimental studies (directed to long-term exposure threshold effects determination), as well as the data of peer rewied scientific publications. Hygienic norms are developed for discrete frequency ranges in account of hygienic safety factor. Today EMF occupational exposure hygienic standards include: hypo-geomagnetic conditions, static electric and magnetic fields, $50 \mathrm{~Hz}$ electric and magnetic field, radiofrequency EMF (from $10 \mathrm{kHz}$ to $300 \mathrm{GHz}$, and special EMF case (ultra broadband pulses). Dose (time-dependence) approach allowed to specify value of EMF permissible levels depending on exposure duration. This approach in radiofrequency range is realised by introduction of 'power exposition' (PE) and 'maximal permissible level' values.

The progress in EMF hygienic safety problem solving is time dependent norms for frequencies from $3 \mathrm{~Hz}$ up to $10 \mathrm{kHz}$ development, as well as attempt of near zone EMF adequate evaluation (for $>300 \mathrm{MHz}$ frequency range) principles.

EMF risks management is based in realisation of protection by distance and protection by protective measures and means too. There are developed new methods of overhead and cable extremely high voltage transmission lines $50 \mathrm{~Hz}$ magnetic field decrease as well as new regulatory documents on requirements and testing of $50 \mathrm{~Hz}$ electric field and radiofrequency EMF individual protective means.

\section{RADON AND RISK OF LUNG CANCER IN APULIA REGION SOUTHERN ITALY}

GM Ferri* ${ }^{*}$ D Cavone, G Intranuovo, F Birtolo, P Tricase, R Fuso, L Vimercati. University of Bari, Italy, Interdisciplinary Department of Medicine (DIM), Section 'B. Ramazzini', Universitary Regional Hospital 'Policlinico - Giovanni XXIIIth', Unit of Occupational Medicine

\subsection{6/oemed-2018-ICOHabstracts. 1200}

Introduction Radon is a naturally occurring radioactive gas and a level 1 carcinogen by IARC. It acts synergistically with cigarette smoke to cause lung cancer. The limit of $300 \mathrm{~Bq} / \mathrm{m} 3$ is envisaged, both for working environments and for living environments, from the new European Directive on the Protection of Ionising Radiant ('Basic Safety Standards' - Council Directive 2013/59/Euratom, published in OJ L -13 of 17/1/ 2014), which will be transposed by Member States of the European Union by the deadline of 06 February 2018.

Method we studied the association between different building, occupational and geologic characteristics and high levels of radon concentrations (above the $75 \%$ percentile). Also the lung cancer death rates for the exposure to Radon was assessed by means of the REID method (Nezahat Hunter, 2015) related to different smoking habits groups. The data collection was carried out using Apulia observed radon data collected by regional environmental protection agency (Arpa), in the provinces of Bari and Lecce and other sources.

Results The preliminary data showed an increase of risk to observe Radom mean values above the 75 th percentile $(100$ $\left.\mathrm{Bq} \cdot \mathrm{m}^{-3}\right)$ associated to years of building above $1972(\mathrm{OR}=2.28$ to $\mathrm{OR}=4.70)$, elevated number of rooms $(\mathrm{OR}=2.16)$, Non cement walls $(\mathrm{OR}=2.6)$. The risk rate due to residential radon will be calculated and differentiated for Continuing smokers, Ex-smokers and Never smokers. The calculations of specific lung cancer rates will be based on the REID method.

Discussion Radon exposure is the second cause of lung cancer. Many lung cancer cases could be prevented in Apulia by reducing indoor radon and smoking habits. The regional and provincial health authorities would be benefited by improved testing for radon and subsequent home remediation rates. Safety structural building procedures could be useful for lung cancer prevention.

\section{ELECTROMAGNETIC FIELDS: OCCUPATIONAL EXPOSURE AND PREVENTION IN WORKERS. AN UPDATE}

Fabriziomaria Gobba. University of Modena and Reggio Emilia, Modena, Italy

\subsection{6/oemed-2018-ICOHabstracts. 1201}

Aim of special session Electromagnetic Fields (EMFs) are virtually ubiquitous, and the large part/almost all workers are virtually exposed. Consequently, an adequate prevention of the occupational risk related to EMFs exposure is important, as recognised by authoritative Institutions as ILO and WHO. In Europe a specific Directive, the 2013/35/EU, recently implemented in European Countries, introduced occupational limits, and the legal requirement of health surveillance of EMF exposed workers. Aim of this Special Session is to give an update on activities currently ongoing for the prevention of the occupational EMF risk, and on the problems of the 